\title{
Converging technologies in teacher education: key issues, key competencies
}

\author{
Paul Nicholson and George Duckett \\ Deakin Centre for Education and Change \\ 662 Blackburn Road, Clayton Australia 3168
}

\begin{abstract}
While converging technologies have had an enormous impact on industry and commerce, their impact on education is only now beginning to be felt as the Information Super Highway finds its way into ever increasing numbers of classrooms. Its move into schools has not occurred as fast as one might have expected two years ago, a situation common in regard to the general infiltration of new technologies into schools (Cornu, 1995). The reluctance of teachers to change is the major noneconomic reason for the low uptake. Students however are keen to experience the new media. The challenge for teacher education is to produce teachers who can adapt this technology to their needs before the technology makes schools themselves irrelevant.
\end{abstract}

\section{Keywords:}

Teacher education, attitudes, future developments, innovation, pedagogy, teaching methods

\section{INTRODUCTION}

This paper is written in response to the following questions:

1. Will converging technologies and globalisation bring about the death of schools?

2. What role will 'teachers' have in the new, potentially information-rich, virtual environments?

3. How will teachers learn to 'teach' in these environments?

4. How will teachers conduct a 'class' with a virtual, loosely-structured group of learners?

These questions, whilst long standing, are suddenly timely and relevant as the advent of global communications and broadband networks brings rich and varied sources of information into the family home. Globalisation, the emergence of global technology and communication systems controlled by global companies, has the potential to reduce educational diversity and to develop global, corporate, and business oriented 
models of education. Additionally it creates a significant pressure for educational systems to adopt their current technology by offering images of '...utopian educational futures made available on line' (Kenway, 1995) with the corollary that schools that fail to adopt the technology will have no future. They find themselves driven and transformed by three linked factors (Tinkler, Lepani and Mitchell, 1996):

1. increased competition for increased market share in a global education economy,

2. changing market requirements for services with the shift to a knowledge economy,

3. the transformative impact of information technologies on the structure and organisation of the education industry in responding to these imperatives.

Teacher education, as a 'responding industry', must clearly change, but it must make the kinds of changes that will maximise educational quality in teaching and learning, and not simply respond to the uncritical, consumer-like adoption of the technology for its own sake. The fundamental epistemological battle to be fought is for the belief that the technology on its own is educationally pointless - that only with skilled intervention and guidance from teachers will these new technologies be educationally valuable and viable, a point which Riel (1990) makes strongly in defending Information Technologies from Cuban's comments on the failure of technology to significantly restructure education (Cuban, 1986).

\section{PERSPECTIVES}

Bigum and Kenway (1996) identify four philosophical and functional perspectives on this issue:

1. Boosters (the unequivocal promoters of new information technologies in education),

2. Anti-schoolers (to whom schools are unable to be reconstructed or reconfigured using computer technology - they should simply be scrapped),

3. Critics (those sceptical about many of the claims advanced for using the new information and communication technologies in education),

4. Doomsters (unqualified opponents of the new information and communication technologies).

In this paper we wish to follow a scenario based mainly on assumption that the technology will be omnipresent, and that the boosters and anti-schoolers' perspectives will prevail (Negroponte, 1995; Papert, 1987; Papert, 1993; Schwartz, 1991). In this scenario, a post-industrial world (Toffler, 1980) has rendered schools irrelevant, and, as products of the industrial revolution ...

'... schools it is argued, are unable to be reconstructed or reconfigured using computer technology. They should simply be scrapped.' (Bigum and Kenway, 1996; Perelman, 1992).

The potential realities of this outcome are significant in terms of redefining teaching and learning ... 
... a totally 'wired' world, one in which classrooms, kids, teachers, the home are all permanently connected to a global computer network. They see such a world offering high quality access to information, remote and world-wide-expert teachers and other learners around the globe. Teachers who have not adapted to this massive shift in the way that schools operate have been discarded. There are no problems in terms of equity and access since the technology has become so affordable and available (Bigum and Kenway, 1996).

\section{NATIVES AND IMMIGRANTS}

In considering the role of teacher education in this brave new technological world, assuming that it has a role, it is important to consider the likely responses of teachers and students to such a radical systemic change. Already Barlow (1995) has raised serious concerns about the fundamental cultural and technological differences between teachers and students - students who are 'natives' in this environment being taught by 'immigrant' teachers who do not understand the power and potential of the technology. Many teachers are also hesitant to adopt the technology and demonstrate low levels of computer literacy (Mitchell, Paprzycki and Duckett, 1994). For example, while students have rapidly understood, appreciated and assimilated the ease of access to information that the Internet provides into their educational activities, most teachers have not. Teachers frequently find it difficult to comprehend that the school and the family home today are both flooded with masses of unstructured, cheap and uninterpreted information. (However this should not be taken to mean that students can actually interpret and organise this material into a coherent cognitive structure.) Teachers have found, to their dismay, that technologically aware (native) students can trivialise cherished, long-standing educational practice with some minimal Internet skills. Such mismatches in competence and knowledge are common in many classrooms today.

Unfortunately the educational future will include both small and large scale cultural clashes between the natives and the immigrants as access to the technology becomes cheaper and more common. In addition to changing schools, teachers themselves will have to be reconstructed to cope with the changed nature of technology, and the purpose of schooling in general.

In the longer term, this will be less of a problem as 'native' students move on to teacher-education institutions (which may then face a serious challenge themselves). While there is a rich literature on the future directions of teacher education, there is little action.

\section{THE DEATH OF SCHOOLS?}

Schooling as a means of transmitting knowledge appears to be in imminent danger of being bypassed by converging technologies. Already there is evidence of widespread informal learning occurring as students browse the Internet from home, using equipment frequently far in advance of what they have access to at school. A scenario based on this becoming a 'normal' way of learning would see schools and teachers having to radically readapt, changing both purpose and pedagogy. This fundamental 
contemporary restructure of the pathways to knowledge has led to an ego-centric model of learning rather than an institution-centred model. Comparing the changes from 1900 to today, the reality of this is enormous, yet still schools persist with the belief that it is not happening. Many studies have shown that this is partly due to teacher resistance to change, and to their low levels of computer skills and confidence (Paprzycki, Mitchel and Duckett, 1994).

\section{VIRTUAL TEACHING ENVIRONMENTS}

Our future teachers will require a very different skill-set from those currently imparted by teacher education institutions. These new competencies will require virtual practicum experiences, conducting on-line classes, as well as the ability to create virtual learning spaces/lessons with enhanced collaborative software environments such as traditional and graphical MUD's and MOO's like Palace (Time Warner, 1996) and rich multimedia bulletin boards and web software tools that are now appearing. Figure 1 shows an example of the environment of a typical virtual classroom (http://www.deakin.edu.au/edu/MSEE/GENII/GENII-Home-Page.html). The teachers challenge is to turn this basic graphic displayed on a computer screen into a productive and rich on-line learning space.

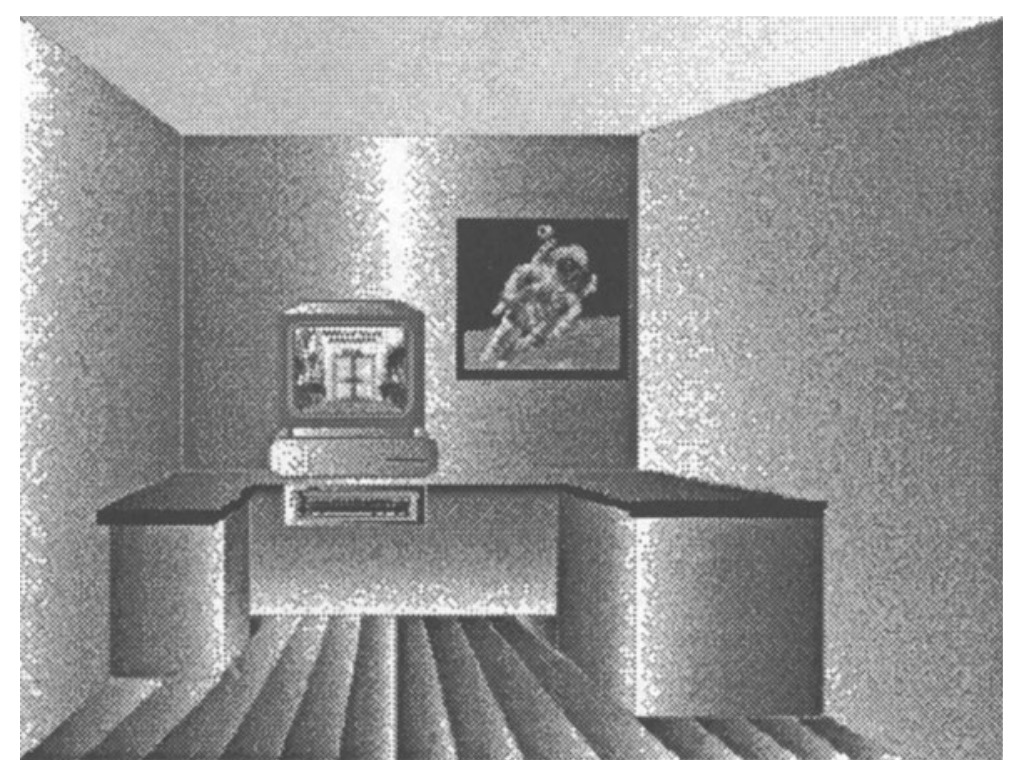

Figure 1 The starting point for a virtual classroom

Even sophisticated graphics, video and speech do nothing to address the pedagogical issues. For example, the more refined 'study' in Figure 2 provides a visual clue to its purpose, but is curiously modelled after a 19th century metaphor, one of the many mixed metaphors found in these environments. However there is no inherent pedagogy in this graphic, other than to suggest it is a place for discussion. 


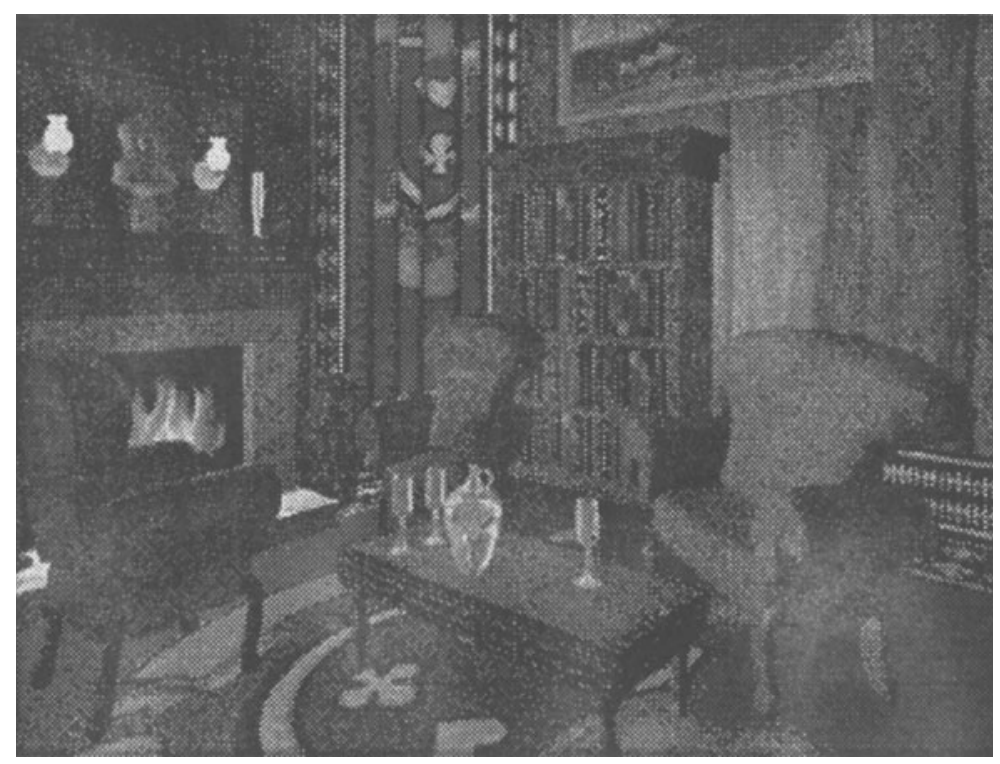

Figure 2 A virtual study based on 19th century models

How will our new teachers gain the knowledge and skills to develop these sorts of environments (or will all future teachers have to be programmers?) How will they acquire competency in their use? And exactly what is an appropriate pedagogy? Is it hard coded into the script, or does the script have to be designed to produce a learning environment in which good pedagogy can occur? These are critical challenges that must be addressed as part of the changing expectations of the education industry.

Treating teaching issues as programming concerns may be quite invalid of course, but the transition from real to virtual teaching environments requires enormous discussion about the design, nature and purpose of teaching. Adopting Barlow's 'critics' stance, the real question is basically how much of the present culture and nature of teaching are we prepared to forgo simply to embrace the technology. The balance sheet of gains and losses needs to be examined very carefully, and not simply from an economic perspective.

\section{CHALLENGES}

A key question for teacher education institutions is how much emphasis should be placed on these new skills at a time when the majority of teaching is still conducted in a traditional didactic classroom mode. However, the decision may not be theirs to make. For example, Don Hayward (Minister of Education, state of Victoria), predicts that traditional classrooms may be non-existent by the year 2000 (Bushfield, 1996). Ultimately it will be the availability of information outside school - the very institutions set up to pass on information to the next generation - that forces change in teacher education. 
Like Papert's time-travelling surgeons (Papert, 1993), our teacher education institutions face becoming irrelevant by failing to understand both the nature and dimensions of the changes that they face. When IT is included in teacher education courses, it is frequently synonymous with word processing, database and e-mail.

The kinds of competencies that are becoming increasingly significant in the context of a 'wired society' are those that accept its presence, and acknowledge that a major revolution in education practice has, or is, occurring. Typically, the kinds of competencies expected of teachers today should therefore include such things as (NBEET, 1995):

- the use of computer-based services to search and find relevant information in a range of contexts for goal-oriented learning tasks.

- the ability to retrieve information using a variety of media.

- the ability to decode information in a variety of forms - written, statistical, graphic.

- the critical evaluation of information, including the use of systems thinking to explore the interconnectedness of different fields of knowledge in a context dependent manner.

- the use of computer-based services to analyse, present and communicate information to create knowledge and insight.

- the use of information technologies to create/use networks of co-learners in the pursuit of knowledge and information sharing.

- the ability to plan and conduct teaching using a variety of telecommunications environments, including virtual and real-time systems.

Sadly, when we compare these with current practice, there is a major discrepancy. Teacher education programs are still grounded in essentially outmoded models of education. Their failure to adapt in a very short time scale will see their demise and the possible death of schools as we currently conceptualise them. We must act now to ensure that this does not mean the rise of "corporate edutainment" as its replacement. The impact on society would be profound and extremely difficult to redress, especially in Western societies where economic discourse dominates the political agenda. At risk is the fundamental tradition of a liberal-egalitarian model of education. Its replacement in a globalised economy would surely give the Cyberspace fantasies of William Gibson some sense of imminent reality - one that many of us would not wish to share.

\section{REFERENCES}

Barlow, A. (1995) Natives and Immigrants to Information Technology in Education. AP, July, 34-36.

Bigum, C. and Kenway, J. (1996) New Information technologies and the ambiguous future of schooling - Some possible scenarios, in A. Hargreaves, A. Leiberman, M. Fullan et al (eds.) International Handbook of Educational Change. OISE, Toronto, Canada.

Bushfield, W. (1996, Tuesday February 27) Pupils outdo teachers in new skills. The Herald Sun, p. 9.

Comu, B. (1995) New Technologies: Integration into Education, in D. Watson and D. Tinsley (eds.) IFIP Transactions A: Integrating Information Technology into Education, A-34, 311. North-Holland, Amsterdam. 
Cuban, L. (1986) Teachers and Machines: The Classroom use of Technology since 1920. Teachers College Press, New York.

Duckett, G. et al (1995) Athena University -VOU and GENII: A Model of Conceptual Change and Collaboration, in J. L. Schnase and E. L. Cunnis (eds.) CSCL'95: Computer support for collaborative work, p. 94, Bloomington, Indianna.

Kenway, J. (1995) Reality Bytes: Education, Markets and the Information Super-highway. The Educational Researcher, 22, 1, 35-65.

Mitchell, T., Paprzycki, M. and Duckett, G. (1994) Computer Literacy: A Global Perspective, in G. H. Marks (ed.) Mathematics/Science Education and Technology, pp. 114-117. AACE, Charlottesville, VA.

NBEET (1995) Converging Technology, Work and Learning. National Board of Employment, Education and Training, Canberra, Australia.

Negroponte, N. (1995) Being Digital. Knopf, New York.

Papert, S. (1987) Computer Criticism vs. Technocentric Thinking. Educational Researcher, 16, 1, 22-30.

Papert, S. (1993) The Children's Machine: Rethinking School in the Age of the Computer. Basic Books, New York.

Paprzycki, M., Mitchel, T. and Duckett, G. (1994) Computer Literacy and Competencies: Preparing Teachers for the Information Superhighway. Paper presented at the Eighth Annual Southeastern Small College Computing Conference, Furman University, Greenville, South Carolina.

Perelman, L. J. (1992) School's out: hyperlearning, the new technology. William Morrow, New York.

Riel, M. M. (1990) Co-operative Learning through Telecommunications, in A. McDougall and C. Dowling (eds.) Computers in Education: Proceedings of the Fifth World Conference on Computers in Education, pp. 467-474. Elsevier, Amsterdam.

Schwartz, P. (1991) The Art of the Long View. Doubleday, New York.

Time Warner (1996) PALACE Moo Software. Time Warner, Los Angeles.

Tinkler, D., Lepani, B. and Mitchell, J. (1996). Education and Technology Convergence: A survey of Technological Infrastructure in Education and Professional Development and Support of Educators and Trainers in Information and Communication Technologies (Commissioned Report Number 43). Department of Employment, Education and Training, Canberra, Australia.

Toffler, A. (1980) The Third Wave. Bantam Books, New York.

\section{BIOGRAPHY}

Paul Nicholson taught science and computing in secondary schools before moving to the tertiary sector as a lecturer in educational computing. Since 1988 he has coordinated postgraduate computer education courses at Deakin University. His Ph.D. studies are in the use of computer probes and simulations as tools for probing cognition in physics. He is the joint chair of the RICE (Research in Computer Education) group at Deakin University. The group, currently actively involved in major national and international research and development projects, also provides consultancy and training programs to industry. A number of current research projects are focused on the impact of converging technologies on educational practice. 